\title{
FOUR SQUARE WRITING METHOD APPLIED IN PRODUCT AND PROCESS BASED APPROACHES COMBINATION TO TEACHING WRITING DISCUSSION TEXT
}

\author{
Vina Agustiana \\ Department of English Education, Faculty of Teachers Training and Education, \\ University of Kuningan, Indonesia \\ Email: v.agustiana08@gmail.com
}

APA Citation: Agustiana, V. (2017). Four square writing method applied in product and process based approaches combination to teaching writing discussion text. English Review: Journal of English Education, 6(1), 89-98. DOI: 10.25134/erjee.v6i1.774.

Received: 12-08-2017

Accepted: 23-10-2017

Published: 01-12-2017

\begin{abstract}
Four Square Writing Method is a writing method which helps students in organizing concept to write by using a graphic organizer. This study aims to examine the influence of applying FSWM in combination of product and process based approaches to teaching writing discussion texts toward students' writing skill, the teaching-learning writing process and the students' attitude toward the implementation of the writing method. This study applies a mixed-method through applying an embedded design. 26 EFL university students of a private university in West Java, Indonesia, are involved in the study. There are 3 kinds of instrument used, namely tests (pre and post-test), field notes, and questionnaires. Data taken from students' writing test are analyzed statistically to identify the influence of applying the writing method toward students' writing skill; data taken from field notes are analyzed qualitatively to examine the learning writing activities at the time the writing method is implemented; and data taken from questionnaires are analyzed descriptive statistic to explore students' attitude toward the implementation of the writing method. Regarding the result of paired t-test, the writing method is effective in improving students' writing skill since level of significant (two-tailed) is less than alpha $(0.000<0.05)$. Furthermore, the result taken from field notes shows that each steps applied and graphic organizer used in the writing method lead students to compose discussion texts which meet a demand of genre. In addition, regard with the result taken from questionnaire, the students show highly positive attitude toward the treatment since the mean score is 4.32 .

Keywords: FSWM; combination of product and process based approach, discussion text
\end{abstract}

\section{INTRODUCTION}

At the university level, disciplinary knowledge and understanding are largely exhibited and valued through the medium of writing (Coffin, Curry, Goodman, Hewings, Lillis \& Joan, 2003, p.19). However, writing is considered to be difficult and challenging for most students (Kim \& Kim, 2005). One of the steps leading it to be more troublesome for students to cope with is to have something to talk about (Cook, 2004). It is in line with Nunan (1995) that it is the starting point that often obstructs students from writing. Therefore, students perceive it difficult to start writing since they are in trouble at the time they start to write.

EFL students are required to transfer their ideas into English. This is another problem in writing since they are expected to meet the criteria of a good text which has different writing sentence pattern between source language and target language.

Furthermore, Alwasilah and Sussana(2007) states that the difficulties in writing are not only in using appropriate vocabulary choice, sentence, and paragraph organization to generate and organize ideas, but also in turning such idea into readable text. Therefore, this indicates that there are several things to consider in writing, such as the purpose of writing, the word choices, the coherence, and how the writer convey the message to the reader. 
According to Alwasilah and Alwasilah (2005), the writing problem appears in Indonesian writing classroom, since there are inappropriate writing teaching method used by the teacher. Dealing with this, the teacher are expected to apply the appropriate method in teaching writing which is able to accommodate students' need and goals in writing (Emilia, 2010). In line with this, Gabrielatos (2002, p.1) implies that "in order to be able to select and use appropriate procedures and materials, as well as assess their students' needs and progress, teachers need to be clear regarding the desirable outcomes of a writing program and the processes involved in good writing." This indicates that writing teaching method plays an important role in accommodating students to learn writing.

Four Square Writing Method (FSWM)is one method offered in teaching writing that leads students organize, compose information and concepts, as well as promote thinking about relationship among concepts before they start to write (Robinson, Katayama, Beth, Odom, Hsieh \& Vandersen, 2006). This is a writing teaching method which is applicable across grade levels and curriculum areas (Gould \& Gould, 1999). In addition, FSWM can be applied in every kinds of text, such as narrative, descriptive, and argumentative. This writing method using visual and kinesthetic tools in the form of a graphic organizer consisting of four outside squares to assists students to focus on their writing (Gould \& Gould, 1999). This aims that students are able to compose a written product logically, coherent and relevant which meets the needs criteria of a good writing.

There are several studies conducted focusing on the implementation of FSWM, such as Wijiastuti (2010) and Ullah (2013). Wijiastuti (2010), through classroom action research design, found that the students' mean in writing score has improved from 55.7 (the first cycle) to 71.57 (the second cycle). In addition, Ullah (2013), through classroom action research, combined the FSWM and product based approach. The findings covered that the students' writing skill has improved since there is improvement in result of students' writing test that $55.56 \%$ of students reached the minimum score of writing in the first cycle, while there is $88.89 \%$ of students reached the minimum score of writing in the second cycle. Based on findings, it indicates that FSWM is effective in improving students' writing skills. Since, FSWM is the method offered in the pre-writing stage prior to producing the final draft, the researcher conducted a research which combined FSWM and product-process based approaches combination in writing discussion texts.

There are 10 stages in product-process based approaches combination (Agustiana, 2016). In stage 1 (modeling) and stage 2 (practicing), students are expected to cover writing goals, generic structures, and linguistic features of a text. In stage 3 (brainstorming), stage 4 (planning) and stage 5 (mindmapping), the students are expected to organize ideas to write. In stage 6 (writing the first draft), the students make the first draft. In stage 7 (peer feedback), the students give feedback toward their friends' text, and vice versa. In stage 8 (editing), the students revise their first draft which has been given feedback. In stage 9 (writing the second draft), the students compose the final draft. In stage 10 (evaluation \& teacher's feedback), students' final draft is evaluated by the teacher.

Considering that FSWM is suit to apply in pre-writing stage, the researcher applied the FSWM in organizing ideas stage, namely stage 4 (planning) and stage 5 (mind-mapping). Thus, the implementation of FSWM in organizing ideas stage in product-process based approaches combination is expected to help students organize their ideas in order to compose a written product which suits to its social function, generic structure, and linguistic features. There are three objectives of this present study, namely the influence of the implementation of the writing teaching method toward: (a) students' writing skills, (b) teaching-learning writing activities, and (c) students' attitude toward learning writing.

The stages of the combination of product and process based approach is shown in Table 1. According to Table 1 , there are 10 stages of 
FSWM in product-process based approaches

which take place in seven meetings.

Table 1. Stages of FSWM in product-process based approaches

\begin{tabular}{rlr}
\hline Meeting & Stages & FSWM \\
\hline 1. & 1. Modeling & \\
\hline 2. & 2. Practicing & \\
\hline 3. & 3. Brainstorming & $\sqrt{ }$ \\
\cline { 2 - 3 } & 4. Planning & $\sqrt{ }$ \\
\hline 4. & 5. Mind mapping & \\
\hline 5. & 6. Writing the first draft & \\
& 7. Peer-Feedback \\
\hline 6. & 8. Editing & \\
\hline 7. & 9. Writing the final draft & \\
\hline
\end{tabular}

In this study, the researcher used discussion text as teaching material. Gerot and Wignell (1994) define discussion text describe discussion text due to its social function, generic structure, and significant linguistic features. The social function of discussion text is to presents (at least) two points of view about an issue. Its generic structures are issue which includes statement and preview; arguments for and against or statements of differing points of view which includes point and elaboration; and conclusion or recommendations. The linguistic features are (a) focus on generic human and generic nonhuman participants, (b) use of comparative; contrastive and consequential conjunctions, and (c) reasoning expressed as verbs and nouns (abstraction).

\section{METHOD}

Regarding the research objectives, this study applied a mixed methods research. Creswell (2014, p.4) states that "mixed methods research is an approach to inquiry involving collecting both quantitative and qualitative data, integrating two forms of data and using distinct design that may involve philosophical assumptions and theoretical frameworks". By mixing the data, this study presents the better understanding of the problem than by using either data set one by one.

This study applied an embedded design. This design is used to answer different questions, which need different types of data to answer (Malik \& Hamied, 2014). The researcher collected both the quantitative and qualitative data during the study. This study is qualitative in terms of collection and analysis of observation data (field notes). Meanwhile, it is quantitative in dealing with test scores and responses to questionnaire. There were three sources of evidence, namely observations (field notes), tests (pre-test and post-test), and questionnaires. Data collection was conducted in nine meetings. There were $26 \mathrm{EFL}$ university students of a private university in West Java, Indonesia, involved in this study,

The first data source was students' tests. The tests were used to find the effect of the implementation of FSWM in product-process based approaches combination on the students' writing skill. In this study, the tests consisted of pre- test and post- test. In each test, the students were expected to create a discussion text with the topic given.

The second data source was field notes. Field notes were primary data to explore the learning writing activities during the implementation of FSWM in product-process based approaches combination. In this case, the researcher played a role as a participant observer who involved in activities at the research site (Creswell, 2012). Field notes were taken for seven meetings. The teacher noted the activities during the process of teaching learning writing after leaving the setting.

The third data source was questionnaires which aimed to describe the students' attitude toward the implementation of FSWM in product-process based approaches combination. A set of closed-ended 
questionnaires was used. All students were asked to choose one choice in the questionnaires that best describe their feeling toward the items. The questionnaires were in Likert-Scale form. It consisted of 25 items, which belonged to two major themes, namely the general attitude toward the implementation of FSWM in product-process based approaches combination, and the attitude toward each steps of writing teaching method. The first theme consisted of five categories, namely motivation, effectiveness, learning situation in the class, comparison with other approach, and the ease of the step. The second theme consisted of 10 categories, namely modeling, practicing, brainstorming, planning, mind mapping, writing the first draft, peer-feedback, editing, writing the second draft, and evaluation and teacher's feedback. The items were analyzed by three aspects, namely affective, behavioral, and cognitive views (Oskamp \& Schultz, 2005).

In analyzing the data obtained, the researcher used qualitative and quantitative data analysis according to the types of data gathered. With regard the validity of the study, the students' tests including pre-test and posttest were scored by two raters. The first rater was the researcher, and the second rater was a writing lecturer in that university. In order to have the same perception in assessing the students' tests, the researcher and the other rater discussed the writing scoring rubric assessment used in the study in order to have the same perception in scoring the students' texts. Afterwards, the pre-test of the first rater was calculated with the pre-test of the second rater to find the final scores of the students' pre-test. Furthermore, the post-test of the first rater was calculated with the post-test of the second rater to find the final scores of the students' post-test.

The scores were calculated to examine the effect of $F S W M$ in product-process based approaches combination on the students' writing skill. This aimed to test the null hypothesis of the study which stated that FSWM in product-process based approaches combination is not effective in improving the students' writing skill. There were several steps to test the hypothesis, namely normal distribution test, homogeneity of variance test, and comparing means. To avoid the error in calculating the data, data taken from the test were analyzed by SPSS 20.0 for Windows.

The second instrument was field notes which were analyzed qualitatively through some steps, namely: (a) Reading the field notes; (b) Identifying the learning writing activities in every stage of teaching writing; and (c) Presenting the evidences of every activity of each meeting into a written form.

The third data sources, questionnaires, were analyzed by descriptive statistics. Descriptive statistics is used to summarize data (Hatch \& Farhady, 1982). Before being calculated, the sets of closed-ended questionnaires were sorted. If the whole items were not filled, the data were not taken, avoiding the invalid data. The questionnaire used the five-point Likert-Scale. The scales were Strongly Agree (5), Agree (4), Uncertain (3), Disagree (2), and Strongly Disagree (1). The scores were calculated by using Microsoft office excels in order to simplify their tabulation. The scores were analyzed based on five level of the students' attitude, namely highly positive, positive, normal, negative, and highly negative as shown in Table 2 .

Table 2. The categorization of students' attitude level

\begin{tabular}{cc}
\hline Students' Attitude Level & Range of Score \\
\cline { 2 - 2 } & Item Level \\
\hline Highly Positive & $4.201-5.0$ \\
\hline Positive & $3.401-4.20$ \\
\hline Normal & $2.601-3.40$ \\
\hline Negative & $1.801-2.60$ \\
\hline Highly Negative & $1.00-1.80$ \\
\hline
\end{tabular}


RESULTS AND DISCUSSION

The influence of FSWM in product-process based approaches combination towards students' writing skill

This section discusses whether FSWM in product-process based approaches combination is effective in improving students' writing skill. Pre-test was conducted in the first meeting of study which aimed at measuring students' prior writing skill in writing discussion text. Meanwhile, post-test was conducted in the ninth meeting of study which aimed at measuring students' writing skill after learning writing discussion text by using FSWM in product-process based approaches combination. Data taken form tests were analyzed quantitatively using SPSS 20.0 for Windows. Statistically, there were three kinds of test conducted, namely normal distribution test, homogeneity of variance test, and comparing means.

The first test was the normal distribution test which aims to find whether the data was normally distributed. The Kolmogorov-Smirnov Statistic was applied in this study. The result of the normal distribution test was shown in Table 3.

Table 3. The result of the normal distribution test

\begin{tabular}{|c|c|c|c|}
\hline \multicolumn{4}{|c|}{ Tests of Normality } \\
\hline & \multicolumn{3}{|c|}{ Kolmogorov-Smirnov $^{\mathrm{a}}$} \\
\hline & Statis & & Sig. \\
\hline PreTest & 140 & 24 & ,200* \\
\hline PostTest &, 162 & 26 &, $079^{*}$ \\
\hline
\end{tabular}

The level of significance as the result of the normal distribution test would be compared with the alpha level. The alpha level was set at 0.05 . Table 3 showed that the score of pre-test's level of significance in normal distribution test was 0.200 . Thus, the pre-test's level of significance was higher than the alpha (0.200>0.05). Therefore, the data of the students' pre-test was normally distributed.

On the other hand, regarding the data taken from the post-test, Table 3 showed that the post-test's level of significance in normal distribution test was 0.079 . Since the posttest's level of significance was higher than the alpha $(0.079>0.05)$, the data of the students' post-test was normally distributed. In conclusion, the result of normal distribution test showed that the data taken from the students' pre-test and post-test were normally distributed. Thus, the hypothesis testing used the parametric statistics, namely t-test.

The second test was the homogeneity of variance test which aims to find whether or not the data is homogenous. The Levene Statistic was used to test homogeneity of variance of the data. The result of the homogeneity of variance test was shown in Table 4.

Table 4. The Result of homogeneity of variance test

Test of Homogeneity of Variances

\begin{tabular}{cccccc}
\hline Levene Statistic & df1 & & df2 & & Sig. \\
\hline 1,936 & & 5 & & 14 &, 152 \\
\hline
\end{tabular}

The level of significance as the result of the homogeneity of variances test was compared with the alpha level. The alpha level was set at 0.05 . Based on Table 4, it showed that the level of significance was 0.152 which was higher than the alpha $(0.152>0.05)$. Therefore, the students' score of pre-test and post-test were homogenous.
The third test was the comparing means test which aims to test the hypotheses of the study. The hypotheses testing was analyzed by using the paired t-test since the means compared were the mean score of the students' pre test and post-test of a group of students. There were two hypotheses set of the study, namely: 
- $\mathrm{H}_{\mathrm{o}}$ : FSWM in product and process based approaches combination is not effective in improving the students' writing skill.

- $\mathrm{H}_{1}$ : FSWM in product and process based approaches combination is effective in improving the students' writing skill.
The result of the paired t-test was shown in Table 5.

Table 5. The result of paired t-test

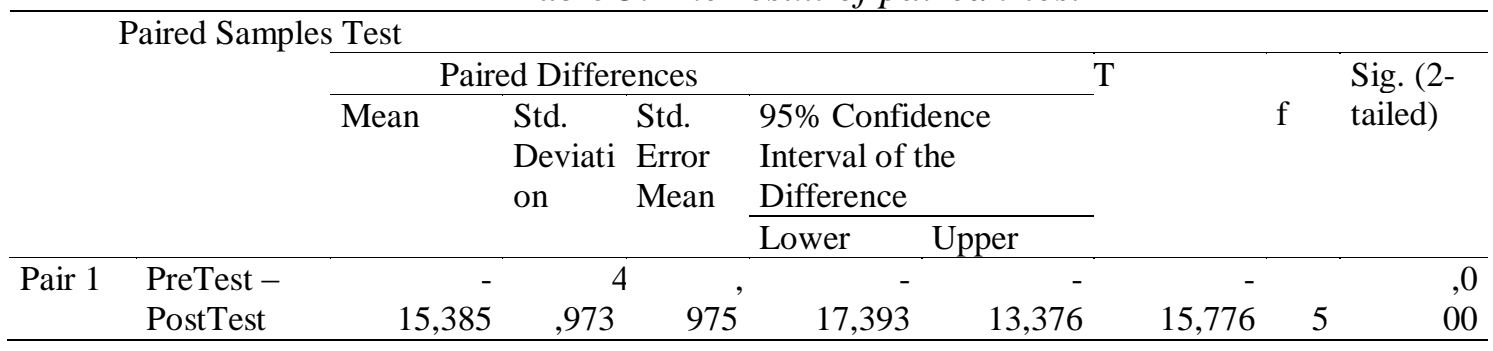

The level of significance as the result of the paired t-test was compared with the alpha level. The alpha level was set at 0.05 . Table5 showed that the level of significance (2-tailed) was 0.000 . It indicates that the level of significance in paired t-test was less than the alpha $(0.000<0.05)$. Thus, $\mathrm{H}_{0}$ was rejected. In other words, FSWM in product and process based approaches combination is effective in improving the students' writing skill.

\section{The process of teaching-learning writing}

This section conveys the process of teachinglearning writing discussion text by using FSWM in product and process based approaches combination. Data was taken from the result of field notes. The process of learning writing took place in seven meetings. They were begun in the second meeting through eighth meeting of study. There were 10 stages in applying this writing method. These would be discussed in the following.

In the first meeting, the teacher applied stage 1 which is modeling. In this stage, the teacher provided a discussion text as a text model. The text fulfilled the criteria of genre in terms of social function, generic structure, and linguistic features. In this stage, the students identified how the writer put the ideas into a written product so that the text discussed two points of view about an issue (Gerot \& Wignell, 1994). Besides, the students also identified the generic structure of the text which consisted of issue, arguments for arguments against, and conclusion and recommendation (Gerot \& Wignell, 1994). Furthermore, the students identified the linguistic features of the text. The result of this stage was the students were able to comprehend the criteria of discussion text regarding the social function, generic structure as well as linguistics feature of the text.

In the second meeting, the teacher applied stage 2 which is practicing. In this stage, the students were expected to use linguistic features found in the text at sentence level. The teacher provided conjunction as teaching material at that day since conjunction is one linguistic feature used in discussion text. The students learnt how to use conjunction in the text appropriately. This was based on the model text they learnt and some practices they conducted. As the result, the students were able to use conjunction, appropriately, after they learnt how to apply the conjunction.

In the third meeting, the teacher provided a topic to students to be developed into a discussion text. In this meeting, the teacher applied three stages of writing, namely brainstorming (stage 3), planning (stage 4), and mind-mapping (stage 5). These stages are stages of organizing ideas. Each stage was applied in a series. At the beginning of study, the teacher applied brainstorming. In this stage, the students wrote their ideas toward the topic given on the white board, so that there would be a group of ideas made by whole 
class students. In this stage, the students actively involved at class in proposing their ideas toward the topic given.

The next stage applied in third meeting was planning in which the students chose the suitable ideas to be developed based on ideas created in brainstorming stage. Afterwards, the students made a plan of writing through arranging the ideas by using the graphic organizer as a tool applied in FSWM. The graphic organizer consisted of four large squares (which were located at the top-right, top-left, bottom-right, and bottom-left) and a small square in the middle.

In arranging ideas by using the graphic organizer, at first, the students put the topic to discuss in a square which was in the middle of the graphic organizer. Afterwards, in the topleft square, they wrote a topic sentence which showed the issue of the text. Next, in the topright square, the students put the topic sentence which stated the pros toward the issue. Subsequently, in the bottom-left square, the students put the topic sentence which shows the cons toward the issue. The next step was the students concluded the text and put the recommendation toward the issue in the bottom-right square. Afterwards, the students wrote keywords which supported each topic sentence in the bottom of each topic sentence made in those four squares. This could be the details, examples or any other words which elaborated each topic sentence. At the end of arranging ideas by using the graphic organizer, the students put the appropriate conjunction in each squares. In this stage, the students found FSWM was helpful in organizing their ideas since the graphic organizer provided squares which could represent the generic structure of discussion text. The process of applying FSWM in the planning stage is attached in Figure 1.

Figure 1. FSWM applied in the planning stage

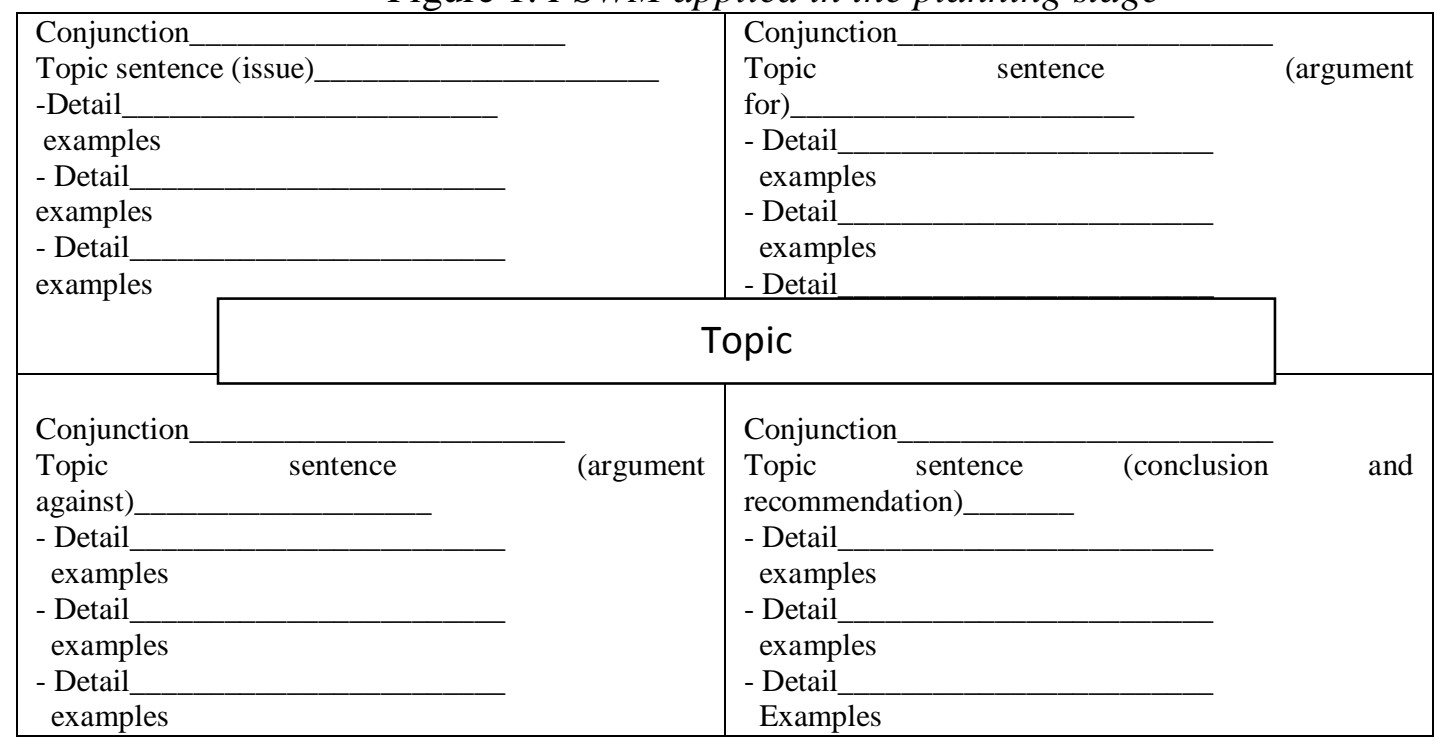

After completing this stage, the teacher applied FSWM in mind-mapping stage as the last stage applied in the third meeting. In this stage, the students were expected to develop the graphic organizer made in the previous stage. Based on Figure 1, there were four large squares which each of them represented the generic structure of a discussion text.

Therefore, the students developed each square into a graphic organizer. Thus, there would be four graphic organizers which each of them represented a paragraph in a discussion text. The top-left square would be developed into a graphic organizer which would be developed into a paragraph which showed the issue. The top-right square would be developed into a graphic organizer which would be developed into a paragraph that conveyed the argument for toward the issue. The bottom-left square would be developed into a graphic organizer which would be developed into a paragraph that discussed the arguments against the issue. 
Lastly, the bottom-right square would be developed into a graphic organizer which would be developed into a paragraph that presented the conclusion as well as recommendation. In this stage, the students were able to develop the graphic organizer created in the planning stage into four graphic organizers which each of them represented the generic structure of discussion text.

In the fourth meeting, the teacher applied writing the first draft stage. In this stage, the students composed their first draft of discussion text by using the ideas they made in organizing ideas stage which was put in the graphic organizers. They were expected to compose a discussion text which met the demand of genre that involved the issue, arguments for, argument against, and conclusion as well as recommendation. In composing this first draft, the students didn't find any trouble since they had made a plan to write in the previous stage by using FSWM.

Afterwards, in the fifth meeting, the teacher applied peer-feedback and editing stage. In peer-feedback stage, each student gave his own first draft to his peer to be evaluated and vice versa. The reviewer evaluated and gave suggestion regarding the sentence and paragraph structure, vocabulary used and so on in order to the text could be more readable. Besides, the reviewer also took the other benefit which was their writing awareness would be improved as they noticed the errors found in their friend's text. In giving feedback, the students used peer-feedback guidelines (as adapted from Agustiana, 2016). However, in this stage, there were some students who were not confident in giving feedback to their friend's text since they thought that their friend had a higher English proficiency than them.

The next stage in the fifth meeting was editing in which the students had their own first draft which had been given feedback by their peers. Then, they revised the text based on the suggestion they got. However, there were some students who didn't get any feedback from their peers since their peers considered the texts had fulfilled the demand of discussion text. Besides, there were also students who didn't take the suggestion given since they thought that their text was good.

In the next meeting which was meeting six, the teacher applied writing the final draft stage. In this stage, the students composed their final draft of discussion text. They used their knowledge and experiences during learning writing by using FSWM applied in product and process based approaches combination. The students paid more attention on their writing final draft than their writing the first draft.

In the last meeting, the teacher applied evaluation and teacher's feedback stage. In this stage, the students' final draft was evaluated by the teacher by using a discussion text rubric assessment (Agustiana, 2016). Besides, the teacher also gave her suggestion toward the students' texts. This aimed at the students could implement any advises into their next writing, so that the students' written product could be better. In evaluating students' final draft, the teacher found that the students had trouble in composing compound sentences as well as complex sentences.

\section{The student's' attitude toward the} implementation of FSWM applied in product and process based approaches combination in writing a discussion text

A set of closed-ended questionnaire which consisted of 25 items was used to cover the students' attitude toward the implementation of the writing method in writing discussion text. It was found that mean score of questionnaires was 4.32 which indicated that the students showed a highly positive attitude toward the implementation of FSWM applied in product and process based approaches combination in writing a discussion text. Furthermore, the top-three of questionnaire item were (a) Conducting Planning stage by using the writing method in writing a discussion text was helpful to focus on topic to discuss in writing (4.73 mean score), (b) Conducting Mind-mapping stage by using the writing method in writing a discussion text was helpful to map the ideas to write (4.69 mean score), and (c) I will conduct planning stage by using the writing method to structure 
my ideas and focus on a topic to develop in writing discussion text (4.62 mean score). On the other hand, the lowest mean score was item 6 which stated that I actively involved at class when the teacher implemented the writing method (4.04 mean score). Otherwise, the lowest score item indicated that the students showed positive attitude toward the implementation of the writing method in writing discussion text.

\section{CONCLUSION}

Regarding the first research objective which aimed to cover the influence of FSWM applied in product and process based approaches combination to teaching writing discussion text toward the students' writing skill, the research finds that the treatment is effective in improving the students' writing skill since the result taken from the paired ttest shows that score of level of significant (two-tailed) is less than alpha $(0.000<0.05)$.

Furthermore, regarding the second research objective which aimed to cover the influence of FSWM applied in product and process based approaches combination to teaching writing discussion text toward the teaching-learning writing process, the research covers that the students finds the treatment is helpful to apply since there is tool used in the writing method named a graphic organizer which leads the students to focus on the topic and develop it in a series based on the demand of discussion text.

In modeling stage, the students are able to comprehend the criteria of discussion text regarding the social function, generic structure as well as linguistics feature of the text.

Furthermore, in stage 2 which is practicing, the students are able to use conjunction, as teaching material at that day, appropriately, after they learn how to apply the conjunction. Afterwards, in stage 3 which is brainstorming, the students actively involve at class in proposing their ideas toward the topic given. Next, in organizing ideas through planning stage by applying FSWM, the students finds FSWM is helpful in organizing their ideas since the graphic organizer as a tool used provides squares which represent the generic structure of discussion text. The next stage is mind-mapping in which the students are able to develop the graphic organizer created in the planning stage into four graphic organizers which each of them represent the generic structure of discussion text. Furthermore, in composing their first draft, the students do not find any trouble since they have made a plan to write in the planning stage by using FSWM. Afterwards, in peer-feedback stage, the research covers that there are some students who are not confident in giving feedback to their friend's text since they think that their friend have a higher English proficiency than they have. In addition, in editing stage in which the students have their own first draft which have been given feedback by their peer, there are some students who do not get any feedback from their peers since their peers consider the texts have fulfilled the demand of discussion text as well as there are also students who do not take the suggestion given since they think that their text is good. At the next stage which is writing the final draft, the students use their knowledge and experiences during learning writing by using the writing method and they pay more attention on their writing final draft than their writing the first draft. Lastly, in evaluating students' final draft, the teacher finds that the students have trouble in composing compound sentences as well as complex sentences. As a whole, the writing method leads the students to organize their ideas better and expects the students to conduct the writing process in a series.

Regarding the third research objective which is to identify the students' attitude toward the implementation of the writing method in writing discussion text, the students show highly positive attitude toward the treatment since the mean score of 25 questionnaire items is 4.32 . It indicates that the students are open to the implementation of FSWM applied in product and process based approaches combination to teaching writing discussion text.

Considering the findings, this research contributes to the theory and educational practice. Theoretically, since the research covers the implementation of writing teaching 


\section{Vina Agustiana}

Four square writing method applied in product and process based approaches combination to teaching writing discussion text

method which is FSWM applied in productprocess based approaches combination to teaching writing discussion text, this research enriches the literature on teaching writing in Indonesian EFL context. This is based on the facts that there is little study existing in Indonesian about the implementation of this writing method, especially at undergraduates' level. Furthermore, this research also gives practical contribution which is the English writing teachers / lectures may implement this writing method in their writing classroom because this writing method is effective in improving the students' writing skill.

\section{REFERENCES}

Alwasilah, A. C., \& Sussana, S. (2007). Pokoknya menulis: Cara baru menulis dengan metode kolaborasi. Bandung: Kiblat Buku Utama.

Alwasilah, A. C., \& Alwasilah, S.S. (2005). Pokoknya menulis. Bandung: PT Kiblat Utama.

Agustiana, V. (2016). Combination of product and process based approaches to teaching writing discussion text. English Review: Journal of English Education, 4(2), 195-208.

Coffin, C., Curry, M. J., Goodman, S., Hewings, A., Lillis, T. M. S., \& Joan. (2003). Teaching academic writing. London: Routledge.

Cook, M. (2004). A fun way to generate ideas for comparison paragraphs. The Internet TESL Journal, 4(10).

Cresswell, J. W. (2012). Educational research (4 $\left.4^{\text {th }} e d.\right)$. Boston: Pearson.

Cresswell, J. W. (2014). Research design: Qualitative, quantitative and mix methods approaches. New Delhi: Sage.

Emilia, E. (2010). Teaching writing, developing critical learners. Bandung: Rizqi Press.
Gabrielatos, C. (2002). EFL Writing: Product and Process. Retrieved from http:// www.gabrielatos.com/Writing.pdf [25 Aug-14, 10:10 a.m.]

Gerrot, L. \& Wignell, P. (1994). Making sense of functional grammar. Australia: Gerd Stabler.

Gould, J.S., \&Gould, E.J. (1999). Four square writing method: Grade 3-5. Carthage, IL: Teaching and Learning Company.

Hatch, E., \& Farhady, H. (1982). Research design and statistics for applied linguistics. London: Newbury House Publishers, INC.

Kim, Y. \& Kim, J. (2005). Teaching Korean university writing class: Balancing the process and the genre approach. Asian EFL Journal Online, 7(2), 69-90. Retrieved from http://www.asian-efljournal.com/June_05_yk\&jk.php [25 Jan- 2014, 09.16 a.m.].

Malik, R. S. \& Hamied, F. A. (2014). Research methods. Bandung: UPI Press.

Nunan, D. (1991). Language teaching methodology: A textbook for teachers. London: Prentice Hall International.

Oskamp, S. \& Schultz, P. W. (2005). Attitudes and opinion $\left(3^{\text {rd }} e d\right)$. London: Lawrence Erlbaum Associates.

Robinson, D. H., Katayama, A. D., Beth, A., Odom, S., Hsieh, Y., \& Vanderveen, A. (2006). Increasing text comprehension and graphic note taking using a partial graphic organizer. The Journal of Education Research, 100(2), 103-111.

Ullah, W.O.R.Y. (2015).Improving students' writing skill using four square writing method. Proceeding of the Seventh International Conference on Applied Linguistics $\left(5^{\text {th }}\right.$ ed $)$.

Wijiastuti, S. F. (2010). Improving students' writing skill using four square writing method (A collaborative action research at the eighth grade students of SMP Negeri 19 Surakarta in 2009/2010). Unpublished paper. Sebelas Maret University. 